\title{
Exchange-Rate Management in Eastern Europe: A Public-Choice Perspective
}

\author{
ENRico COLOMBATto \\ Università di Torino, Torino, Italy \\ and \\ JONATHAN MaCEY \\ Cornell Law School, Ithaca, New York
}

The paper presents a public-choice analysis of the existing exchange-rate regimes in transition economies, with special reference to Eastern Europe. The links between policy making, rent seeking and exchange-rate regimes are thus examined in detail from a theoretical point of view, and then compared with the existing empirical evidence. Some comments about the role of the West and of international organizations are also put forward.

\section{Issues in the Choice of an Exchange-Rate Regime}

The adoption of a satisfactory exchange-rate regime has been one of the most prominent issues that policy makers in Eastern Europe have been facing since the transition process began some 5 years ago. Such prominence is justified from several viewpoints. The exchange rate has often been identified as a "prestige" variable, with respect to which politicians in all countries tend to be fairly sensitive. ${ }^{1}$ In addition, it is often an

We are deeply grateful to Peter Botousharov, for his comments and very substantial contributions to various parts of this paper. We are also indebted to Jean Pierre Centi, Anthony De Jasay, Deepak Lal, Fred McChesney, Russell Osgood, Giovanni Pavanelli and John Pippenger for their comments on preliminary versions, which have also benefitted from presentations at Cornell and at George Mason Law Schools, as well as at the Centre d'Economie Appliquée de l'Université d'Aix-Marseille.

'This applies both to industrialized countries and to less developed countries (LDCs). One may recall currency policies in the mid-1920s, or to the Canadian experience during the Great Depression; more recently, one may refer to the French-Franc policy and desiderata vis-a-vis the Deutsche Mark, especially in the 1960s and in the 1970s; or to the Italian Lira and the British Pound in 1992 (in both cases substantial amounts of foreign currency reserves before giving in to devaluation); or to most LDCs (including the Communist bloc before transition), where the domestic currency was pegged to some "prestige" currency, and then made irrelevant on international financial markets by denying convertibility (so as to resist pressure to devalue). 
attractive tool for economic policy, for instance, the imbalances caused by an expansionary monetary policy may be corrected by devaluation.

To simplify matters, one may say that the choice of the appropriate exchange-rate regime boils down to the role of convertibility, that is, the freedom to buy currencies, assets, and commodities with given amounts of the domestic currency; of course, the price at which such transactions take place (the nominal exchange rate) may be fixed by the central bank, or may be flexible, according to supply and demand conditions.

Clearly, free-market principles suggest the adoption of a convertible, flexible exchange-rate currency. Yet, a more or less cautious neoclassical macro approach usually has been preferred; the choice of the appropriate exchange-rate policy and regime is no longer clear cut. For instance, the emphasis on macro-stabilization has led some to argue that convertibility becomes relevant only after stabilization has been accomplished [cf. Bruno (1993)]. On the other hand, unambiguous technical recipes about fixed and flexible exchange rates are deemed to apply-at best-only to long-run equilibrium configurations, when "all countries end up with a more or less fixed exchange rate ... [while] floating rates are mainly adopted in an initial phase, because of a lack of foreign exchange reserves." 2

Nor does Eastern Europe present a clear picture where both flexible and fixedexchange rate regimes have been adopted, often in the same country (in different periods). As a matter of fact, since both credibility and structural adjustment are badly needed in transition countries, policy prescriptions tend to be contradictory, and exchange-rate theory turns out to be of little help. In addition, policy makers must also take into account the political feasibility of a given conduct; public opinion (whatever that means) may not accept "optimal proposals" and political careers may be endangered. More generally, both the nature of the feasible change and its speed also depend on the initial economic and institutional conditions of the country. ${ }^{3}$

Still, we claim that the choice of the exchange-rate regime is neither random, nor arbitrary. In particular, we maintain that the influence of orthodox exchange-rate economics in most transition economies is modest; rent-seeking phenomena are more likely to prevail, while technicalities provide shelter vis-à-vis potential criticism, or partially disguise welfare redistribution effects. In turn, as recently mentioned in Krueger (1993, ch. 5), the economics of the exchange rate become useful to explain and understand how coalitions are formed, what they want, and possibly what they are likely to achieve.

A public-choice approach thus is made use of to investigate (a) the role of institutions and rent-seeking activities as regards the choice of the exchange-rate policy, (b) the effects of the most relevant exchange-rate policies on the typical bargaining situation in an Eastern European country, and (c) the possible role of international organizations and of the "West" at large to solve-or ease-the public-choice deadlocks on the way to successful transition.

Let us start with convertibility. ${ }^{4}$ As is known, a fully convertible exchange rate leads to efficient relative prices in the tradable sector. But it also leads to imbalances in

\footnotetext{
${ }^{2}$ Cf. again Bruno (1993, p.8).

${ }^{9} \mathrm{~A}$ partial exception to the traditional neglect of these issues is found in Guitiàn (1994), where the choice among different exchange-rate regimes is analyzed by considering the structural features of the country and the political goals of the authorities (but not their self-interest/rent-seeking motivations).

${ }^{4}$ See Greene and Isard (1991) for an excellent survey of currency convertibility in transition economies.
} 
production, due to excess demand in those industries that produced goods the relative price of which was too low before transition took off, and to excess supply in the opposite case. Social unrest and resistance to transition could easily come to the surface.

On the other hand, the lack of convertibility means that relative prices in the tradable sector are the result of the mix between some kind of central planning (foreign-trade controls, in particular, like tariffs, quotas, and licenses) and the interaction between domestic demand and domestic supply under autarky-we shall define this situation as one of "quasi autarky." When a noconvertibility solution is chosen, two possible outcomes can materialize. If the relative-price structure (in tradables) under quasi autarky is somewhere between what it was before transition and what is should be in a freemarket, open economy, then slow transition is under way; and the lack of convertibility allows producers to adjust to the new prices without suffering major shocks. But transition can hardly take place if the prices implicit in centrally planned output are closer to the free-trade price structure than to the quasi-autarkic one.

The above applies to the relative prices of tradable commodities with respect to other tradable commodities; in fact, this is what convertibility is about. Another kind of story applies to the real exchange rate, which is the price of the typical tradable commodity relative to that of the typical nontradable commodity. If it is too weak (high), then tradables will be in excess supply and nontradables in excess demand, whereas the opposite applies to an overvalued real exchange rate.

Of course, under full convertibility, a weak real exchange rate generates a foreigntrade surplus and inflationary pressures ${ }^{5}$; whereas a strong real exchange rate generates a trade deficit plus deflationary pressure and/or unemployment. But if the domestic currency is not convertible, then an unbalanced real exchange rate generates inflation plus unemployment; the weakness or strength of the exchange rate only determines where unemployment is located and where inflationary pressures come from.

As regards the nominal exchange rate, a "fixed" exchange-rate rule is a commitment to carry out a given monetary policy. In particular, the central authority is ready to sell or to buy units of the domestic currency at a given price, which may be constant, or variable in time according to a known rule (the rule-based crawling-peg system, as opposed to the discretionary peg). The obvious benefit associated to this regime is credibility for the policy maker, which is forced to behave "properly" by the limited amounts of foreign reserves available to shield imbalances.

The major flaw with fixed exchange rates is that credibility usually comes before-not after-policy making has been carried out. As De Grauwe (1992, p. 53) has pointed out, merely fixing the exchange rate does not solve the problem, because the fixed exchange rate rule is no more credible than a fixed inflation rate rule. A weak government is likely to take its commitments back, if necessary, rather than carrying out strong policies; the agents know it and don't take the commitment seriously from the very beginning. In other words, a fixed exchange-rate regime can make stabilization easier for a trustworthy government, and thus enhance its credibility, also vis-à-vis foreign investors and organizations, but it can make it harder for "wet" policy makers, for producers and consumers behave inefficiently during the period in which the exchange rate is fixed

\footnotetext{
${ }^{5}$ Of course, inflation is a monetary phenomenon and, if the demand for money is roughly constant, it cannot take place unless the money supply increases. Yet, it is assumed that once inflationary pressures come to the surface in some industries, deflationary pressures in other industries are accommodated by increasing the money supply (say, to finance the budget deficit). This is surely a strong hypothesis from the theoretical point of view; but it is certainly plausible in the light of the recent and not-so-recent experience, both in Eastern Europe and in other parts of the world.
} 
and unsustainable. As Calvo and Végh (1994) point out, money-based strategies are better than exchange-rate stabilization if credibility is low. In fact, the availability of foreign reserves in an economy where policy is inconsistent with a stable nominal exchange rate provokes speculative attacks. Gains by the speculator are equivalent to the reserve losses by the "victim"; the higher the potential losses for the latter, the higher the potential-and indeed, likely-gain for the speculator.

Understandably, Eastern European policy makers have not all made the same decisions, although a balanced-trade requirement and old-style Council for Mutual Economic Assistance (CMEA) principles have frequently come to the surface: "After the dissolution of the Soviet Union the new independent republics imposed taxes and quantitative restrictions on their exports and negotiated bilateral trade agreements. The restricting principles of these agreements was that exports should balance imports. [...] The principle of balance was then exercised by cutting exports if the deliveries of the partner fell behind his promises" [Bofinger et al. (1993) pp. 10, 11]. In particular, the degree of convertibility is highly variable across countries, and so is the attitude towards the real and the nominal exchange rates.

Rent seekers' behavior in transition may be a suitable criterion to understand how choices have been made. For if transition is successful, rent seekers have to decide how to take advantage of the process, and/or how to hold on to old rents, if the transition process is run by the old nomenclature. On the other hand, if transition is in jeopardy, the problem is what to do to avoid social and political reform and thus liquidation of existing coalitions, as predicted in Olson (1982).

\section{Politicians, Rent Seeking, and the Exchange Rate}

Politicians are assumed to pursue two objectives: stay in office as long as possible and maximize their income by taking part in the bargaining game with rent seekers. As a consequence, politicians tend to sell pieces of law-making in exchange for money, power, and prestige. Unless prestige is at stake, the exchange-rate policy is not usually a prominent item on the agenda of political parties or Parliament, for such policy tends to be determined by the government and the central bank. Nevertheless, both are influenced by political pressure, either because they also engage in the bargaining game, or because appointments are of a political nature. The only case when this constraint could be at least partially avoided is where the exchange-rate regime is defined by the constitution. This is certainly the case when the (fixed) exchange rate is run by currency board supervision, a possibility that is seldom taken advantage of, since it would virtually cancel the role of domestic monetary policy and make all changes in the parity much more difficult. ${ }^{6}$

To stay in office a politician has to fulfill expectations and, at the same time, allow the speed and size of wealth transfers to increase only if the rate of growth of the economy is satisfactory, so that nobody's welfare is likely to fall. In other words, transfers are feasible only if perceived as a means to improve welfare significantly in the shortmedium run, and if they do not harm anybody's present welfare too seriously. Deviations from this "golden rule" are of course acceptable for a politician, but only if they

\footnotetext{
${ }^{6}$ Schmieding (1993) provides sound "orthodox" suggestions about how a fixed exchange rate system could be run by a currency board in transition economies, while Bennettt (1993) describes the working of the Estonian currency board.
} 
entail adequate compensation from rent seekers (to balance the danger of being out of office).

\section{Convertibility}

As a consequence, when it comes to the preferred exchange-rate policy, politicians would

- favor a convertible currency if the pretransition specialization pattern within the tradable sector is already close to the ideal configuration. In this case wealth transfers and adjustment costs would be limited, and the economy overall would take full advantage of the international division of labor. In this context convertibility may thus be limited only if lip service must be paid to the bureaucrats, to whom power could be provided by allowing some foreign-trade control, and therefore opportunities for rent-seeking bargaining.

On the other hand, if the relative size of the tradable-good industries is far away from what the comparative advantage pattern suggests, and adjustment costs are too large relative to the increase in welfare generated by the exploitation of comparative advantage, then incomplete convertibility allows politicians to protect the economy from international prices, introduce structural adjustment gradually, and thus avoid political turmoil.

- stick to a nonconvertible currency if the political situation is unstable and hopes to stay in office are virtually nil. For in this case politicians want to maximize their short-term, rent-seeking revenue, which is presumably greater, the greater the amount of central planning (and foreign-trade state monopoly) and of protected monopoly power in each industry. In a no-convertibility state, politicians would be able to extract compensation from the bureaucrats (which would manage the foreigntrade monopoly regime) and incumbent producers would be likely to compensate the politicians more than the eventual beneficiaries from a convertibility regime. Convertibility reduces monopoly power within the country; the amount of directly unproductive profit-seeking activities (DUP) that agents operating in a competitive environment can afford is of course less than that carried out by monopolists.

This can actually turn out to be a self-reinforcing mechanism, whereby a policy chosen because of a limited time horizon may in fact apply to long periods. The soft-budget constraint associated with the rent-seeking policies described above contributes to killing financial markets and thus creates the one condition for such soft constraint to be acceptable to a vast majority of economic agents. Indeed, a hard budget constraint with poor financial markets creates a lot of "losers," but does not make sure there will be winners, because in this environment the resources released by the inefficient firms (which have gone broke) are not employed by the efficient agents within an acceptable time span.

It is then hardly surprising that-ceteris paribus-the desirability of a hard budget constraint decreases as its enforcement is delayed, and that bankruptcy laws tend not to be enforced in slow-transition Eastern European countries.

The size of the country may also play a role. A large market may be appealing to foreign sellers, who can make a profit only if the currency of the country where their goods are sold is convertible: politicians can thus sell convertibility to foreign sellers of commodities. In turn, these will engage in the bargaining game only if some degree of monopolistic power in the new market is guaranteed; otherwise there would be no rent 
to seek and compensate politicians for. On the other hand, the introduction of convertibility is rather hard to repeal, whereas an inconvertible currency can easily be made convertible, if desired. Therefore, ceteris paribus, politicians with a short-term horizon will prefer to strike a one-shot bargain (as the introduction of convertibility surely is, even if at the expense of their successors), rather than sell the stream of rents associated with quasi-autarkic solutions.

\section{The Real Exchange Rate}

Regarding the strength of the real exchange rate, two questions are in order: is a balanced real exchange rate a desirable target and, if not, what kind of imbalance is to be aimed at?

As pointed out in the introductory section, under a convertibility regime, imbalances mean inflation or unemployment, according to the sign of the deviation. But they also create pressures that may offset imbalances generated by other sources; this is surely the case during transition, when unemployment is likely to rise because of adjustment. Therefore, with an eye to elections, a politician may prefer a rather weak real exchange rate, so as to keep labor demand high; on the other hand, if the focus stays on the rent-seeking bargaining game, policy makers may be willing to accept a relatively strong real exchange rate for two reasons. Protectionist pressures in support of the tradable sector will rise and form the object of rent seeking by agents active in those industries; tariffs and subsidies may also be easy to accept by the losers (consumers), in view of the psychological pressure generated by the trade deficit. In addition, by creating excess demand in the nontradable sector, politicians will be supported by those operating in that part of the economy.

In short, a convertible currency and a strong real exchange rate create a lot of room for rent seeking. A weak real exchange rate may speed up transition, and keep unemployment low, but it provokes inflation, with a possibly undesirable change in wealth distribution, social unrest, and an adverse effect on investment (as a consequence of social unrest and inflation).

Under no convertibility policy makers have nothing to fear from the foreign sector, since the economy is isolated from interaction with the rest of the world and imbalances can be created or at least partially corrected with relative ease. Of course, fiddling with the real exchange rate under no convertibility requires some kind of old-style central planning, which may make the bureaucrat happy, but can easily anger consumers.

\section{The Nominal Exchange Rate}

Under no convertibility, the exchange rate is surely fixed (and meaningless), for there is nothing to make it vary.

Under convertibility, the chosen regime conveys two kinds of information. A fixed nominal exchange rate in a transition economy implies restricted capital mobility to restrain speculative attacks. In addition, it suggests that the government is ready to compensate possible imbalances by protectionist intervention on trade flows. Instead, free floating means that the exchange rate is accepted to be the effect of the chosen set of policies, rather than the justification for state intervention. As such, the message is that no exchange-rate policy will be carried out.

The former approach is obviously much more attractive in a rent-seeking perspective, 
for it stimulates coalitions to act and secure the benefits of intervention. Indeed, it is often in the interest of the politicians themselves to stick to a nominal fixed exchange rate, and yet fail to carry out the so-called stabilization policies that would keep the exchange rate in equilibrium at the chosen level. Such failure would justify discriminatory state intervention to the benefit (among others) of policy makers-i.e., politicians and bureaucrats. In this context compliance with the conditional-aid requirements put forward by international agents would be purely accidental; actually, an international commitment to a fixed exchange rate easily translates into an international license to local politicians to interfere with domestic prices.

In addition, even if a convertible, fixed-exchange-rate regime is successful (i.e., no substantial imbalances occur), the benefits of greater prestige may compensate the loss in short-term rent seeking. For instance, in (small) countries where social control is higher-see the Baltic states-short-term rent seeking attempts are likely to be pointless, and politicians are inclined to devote their efforts to longer-run goals, especially if the initial state of the economy is already satisfactory. This is discernible in the case of Estonia, where the foreign side of the economy at the beginning of the 1990s was in relatively good shape (see the speed of trade rerouting, from East to West, not to mention the balanced budget) and where, contrary to Latvia and Lithuania, the authorities could maintain a fixed exchange rate enforced by a currency board (Lithuania enacted a currency-board arrangement effective as of April 1994).

Would then politicians always try to implement a fixed-exchange-rate system? The answer provided by the discussion outlined above is therefore "yes," unless imbalances are too large to be compensated by "reasonable" price intervention, or unless the indexation/anchor rule is such that the local currency is replaced by another currency (dollarization) and the area for rent-seeking bargaining disappears.

\section{Preliminary Conclusions}

In short, convertibility is really the crucial issue. For choice on this point reveals how much central planning the politician wants to keep or introduce, and thus determines the rules according to which the rent-seeking game will be played. In this light, the possible real and nominal exchange-rate strategies are little more than the instruments with which the game is played.

By and large, the above analysis suggests that the most likely policy advocated by a politician during "smooth" transition is bound to be favorable to a fixed-exchange-rate regime and to some convertibility.

As regards the real exchange rate, if the time horizon is short, preference goes to a "strong" policy, so as to create the greatest demand for immediate rent seeking by the counterparts and thus profitable bargaining; the possibility of generating increasingly dangerous distortions and of jeopardizing transition itself plays a minor role, because of calculated political shortsightedness. Practically, this may be accomplished by fixing the nominal exchange rate at a reasonable level without having stabilized prices, so that in a matter of weeks or months the real exchange rate ends up by appreciating significantly.

On the other hand, a politician who wants to stay in office for longer will be more interested in keeping unemployment low by means of a weak real exchange rate and fast transition. The fight against inflation may be sloppy, but if the rise in prices is not too sharp, its consequences may be acceptable in a rent-seeking perspective; politicians would be asked to act to sustain investment and protect the population against wealth 
redistribution. This implies the choice of a relatively high (fixed) nominal exchange rate, so as to guarantee an undervalued currency in real terms for a long enough period to make transition credible, irreversible, and suitable to enforce a more rigorous monetary policy.

A nonmyopic politician going through a "troubled" transition, however, can only go for a flexible exchange-rate regime, which usually implies a variable but appreciating real exchange rate, especially in transition economies ${ }^{7}$. Otherwise the disequilibrium would soon become unbearable.

\section{Other Actors on the Stage}

The counterparts for the politicians are three: bureaucrats, producers, and consumers. Would they object to the line of action described in the Preliminary conclusions part of Section II?

As has been mentioned, the politicians' aim is either to provoke repeated rentseeking bargaining games without damaging transition too much (otherwise the game cannot be repeated by the same rent seekers), or to execute a hit-and-run performance, with little regard to what happens to the transition process.

The bureaucrats' target is even simpler. They want to operate within an environment that is stable enough not to run the risk of being swept away by revolutionary processes, but is troubled enough to provide them with adequate discretionary power, possibly enhanced by some degree of central planning or vigorous state intervention. In this light, bureaucrats may perceive a hit-and-run attitude by politicians as possibly troublesome, because it leads to a rapidly deteriorating situation and possible destruction of existing coalitions.

A stable legislature-or, rather, politicians who want to stay in office for long-is thus a much more attractive picture for the bureaucrat, especially if the transition process is paved with some difficulties. The bureaucrat will therefore be inclined to encourage exchange-rate flexibility and gradualism, ${ }^{8}$ the latter involving some kind of government intervention. Whereas if transition is fast and smooth, bureaucrats will try to restrict convertibility and introduce a fixed-exchange-rate corset, so as to trigger the rentseeking bargaining process, should any imbalance come to the surface.

Private producers' attitude is hard to assess, for there is a sharp difference between "old" producers and "new" producers; the former being those already active in the centrally planned economy, the latter being those who are ready (or think they are ready) to take advantage of the opportunities offered by a transformed economy.

By and large, old producers only are able to form coalitions, since new producers are simply not there. As a consequence, producers' interest groups will try to have a pro-

\footnotetext{
${ }^{7}$ The secular and cyclical reasons for that have already been explored in detail long ago. See, for instance, Balassa (1964), Samuelson (1964), and Stockman (1980).

Other effects also characterized stabilization attempts, for instance, in Latin America, where a free-floating currency plus capital mobility led to a rapidly appreciating real exchange rate, and thus to trouble for the domestic tradable industries.

${ }^{8} \mathrm{~A}$ large body of literature points to the fact that transition is not made easier by gradualism, but by shock therapies; the reason being that gradualism usually implies low credibility for the policy makers and high uncertainty for anybody who wants to start a new business. Yet, shock therapy seems to be feasible only if carried out soon after transition has been announced; whereas gradualism becomes almost inevitable if expectations about the benefits of transition are allowed to drop, so that shock therapy reductions in welfare may be less easily tolerated.
} 
tected economy; either by means of limited convertibility, or by means of convertible currency coupled with an appreciating real exchange rate, so as to be in a favorable position to ask for protection. The nominal exchange rate regime in this case is, of course, irrelevant in the long run; old producers want to see distortions, and they also want everybody to see them, so that the need of state intervention and protection cannot be questioned. In the short run the issue is however more delicate, although preference for the fixed regime is more likely to prevail. For at the beginning, a fixed regime would make the imbalance more rapidly unsustainable, and thus ignite the rent-seeking game earlier; but could also induce the government to reduce the imbalances (and the origins of distortions), and thus resist pressure towards additional intervention. On the other hand, a floating regime would delay the need for subsidies and indeed make entry by new producers easy, but avoid the danger of extreme changes.

Finally, there is the workers' point of view. In general, transition economy consumers ${ }^{9}$ don't care to much about the exchange-rate regime. Rather, they are concerned about the need to acquire Smithian specialization ${ }^{10}$ and skills in a reasonably secure environment. As a consequence, they expect the government to provide some form of guarantee to protect them against possible unemployment, which may well accompany demand or supply shocks in a Smith-like specialization model. ${ }^{11}$

In a country where Smithian specialization has already been achieved the need for social protection is less acute, since there is no need to persuade individuals to cross the bridge from Ricardo to Smith; hence fear of being exposed to international competition, or of being flooded by foreign immigrants, is less intense. The exchange-rate regime remains a secondary subject, and is not perceived as a key element in the transition process. But in countries that suffer from economic and cultural backwardness (as regards the basic concepts of sound economic theory) a Smith-like approach to the division of labor is assumed to provide, at best, potential long-term gains and probable short-term problems. It is not surprising that in this framework a nationalistic approach to economic transition is welcome. Quasi autarky (as defined previously) and a fixed exchange rate become attractive; while failure to comply with these requirements requires compensation-an expanded welfare state or, more generally, a pervasive public presence in the economy.

\section{Some Facts}

\section{Convertibility}

Since the beginning of transition, convertibility has been considered a very binding constraint. In particular, it was clearly perceived that transition, to be credible-both

\footnotetext{
${ }^{9}$ Consumers and workers are assumed to be the same.

${ }^{10}$ Specialization can follow two kinds of patterns. According to the Smithian approach, workers invest in learning so as to be able to increase their productivity by applying their knowledge and learning abilities to a restricted domain of activities. Specialization is necessary to make learning requirements manageable, whereas deskilling is to be avoided. On the other hand, the Ricardo-Babbage pattern assumes that learning is relatively unimportant and that specialization should be acquired through deskilling and task fragmentation.

In the former case, which is more suitable if new technologies are utilized extensively in the economy, workers are imperfect substitutes for each other; in the latter, which is probably more typical of the late 19th century and the first part of this century, they are almost perfect substitutes.

${ }^{11} \mathrm{~A}$ frequent political and social answer to such expectations has been nationalism, which has its economic counterparts in the welfare state and trade protectionism. Cf. Pagano (1993) for a more detailed analysis.
} 
from an economic and a political viewpoint-had to take place within the framework of a convertible currency.

On the other hand, the institutionalization of convertibility was believed to introduce a new, higher degree of economic freedom, which could offer agents a much bigger opportunity to expand production and consumption. Reference was made to the creation of a better environment due to the increased pressure from foreign competition and to the hoped for inflow of foreign direct investment. Of course, this was in sharp contrast with the previous currency regime; despite the often-boasted peg to some "prestige" currencies, in fact the socialist currencies were not convertible at all and had to follow the "annual foreign exchange plan."

On the other hand, at the dawn of transition, convertibility became a political issue per se, in that authorities were convinced that their domestic and international credibility as reformers would be enhanced by a strong commitment to convertibility.

As a consequence, at the outset of the reforms, the new authorities abandoned the annual foreign exchange plans, thereby easing foreign trade restrictions, unified the multitude of exchange rates, made some attempts to create foreign exchange markets, introduced internal convertibility, which is the right given to residents to convert their domestic currency balances into foreign exchange. All that led to limited currentaccount convertibility.

This process took place in two different scenarios. It occurred in the form of a "big bang" in Poland (beginning of 1990), in Bulgaria and in Czechoslovakia (beginning of 1991), and in the Baltic countries (1992). These countries removed virtually all restrictions on foreign exchange for current-account transactions and they liberalized domestic prices and trade activities. But in other countries, like Hungary, Romania, Russia, and Ukraine, these moves were protracted in time. Today, current-account convertibility is almost achieved in most countries in transition. ${ }^{12}$ However, since trade restrictions are still imposed and effective in many countries, commodity convertibility (as defined in Section I), is still highly variable in Eastern Europe.

As regards capital-account transactions, they continue to be strictly regulated in almost all countries in transition, with three exceptions. Estonia, Lithuania, and Latvia have already accepted the obligations of Article VIII of the International Monetary Fund's (IMF's) Articles of Agreement and do not apply any restrictions on inward and outward capital transfers. The alleged reason for keeping these restrictions in most Eastern European countries is to eliminate capital outflows, especially in those cases

\footnotetext{
${ }^{12}$ Of course, the removal of the restrictions is certainly not complete, but the few remaining obstacles to the genuine current account convertibility could be easily removed. In particular, the elimination of external payment arrears has recently been achieved in Bulgaria and Poland. While the remaining exchange rate restrictions are almost exclusively limited to services-related transactions and to the maintenance of balances (often unoperational) under the bilateral payment agreements, mainly with former COMECON countries.

Once these restrictions are removed, the IMF requirements under Article VIII (sections 2,3, and 4) of the Articles of Agreement would be satisfied: a member may not, without the approval of the IMF, impose restrictions on making payments and transfers for current international transactions.

Transitional provisions are nevertheless allowed for under Article XIV, which let countries maintain those restrictions on current-account transactions that were in effect when such countries joined the Fund. However, the IMF (1995, pp. 34-35) acknowledges that "because of strictures against reimposing or introducing new restrictions, member countries have been reluctant to give up their transitional status, even when they have removed all the restrictions sanctioned under Article XIV. Since the IMF's inception, members have accepted the obligations of Article VIII at the rate of less than two a year. Only about one third of developing countries have assumed article VIII status, and one sixth of these countries have reimposed exchange restrictions."
} 
where a fixed exchange rate is believed to be desirable, but subject to attack. ${ }^{13}$ Yet, while outward capital movements remain tightly controlled, most countries now guarantee free repatriation of the investors' profits as well as of the invested capital, with no limitation of timing and amount.

\section{Real Exchange Rates}

Although the achievement of a more or less convertible currency has been an important part of exchange-rate policy in transition economies, the microeconomic behavior of real exchange rates is not an issue per se, but rather is the result of the choices deriving from the need to keep the current account balanced in the presence of domestic inflationary pressures. In other words, the microeconimic view of the real exchange rate was overwhelmed by the size of the macroeconomic imbalances as well as by the existing rigidities.

In particular, since the equilibrium exchange rate is hard to define, especially at the beginning of transition, and since correcting a surplus is usually an easier job than cutting a deficit, it is hardly surprising that a weak-although gradually appreciatingreal exchange rate prevailed, and was made possible, by the initial sharp devaluation in all the Eastern European currencies. The inflationary effects of such weakness were not considered a major question at the time, for prices were expected to rise anyway, to ease adjustment. ${ }^{14}$ At the same time, however, given the far too large size of the nontradable sector in communist countries, weak exchange rates would imply a very significant shift of resources away from the nontradable industries toward tradable industries. In most large-country situations, the adjustment costs involved were deemed to be large enough to provoke possible political pressure (by producers in the nontradable sectors) and turmoil. As a consequence, the effects of weak exchange rates were partially offset by subsidies and by letting the state continue to play a significant role in the economy. Of course, it is hardly worth mentioning that, when this kind of intervention is particularly strong (say, in Bulgaria), the real exchange rate ceases to be a meaningful relative price and no longer has an influence on the allocation and consumption of resources.

\section{Nominal Exchange Rates}

In the process of transformation, Eastern European countries made different exchangerate choices. Despite their common "socialist" background, according to the standard approach such discrepancies were caused by a legacy of dissimilar disequilibria. For instance, Poland, Czechoslovakia, and the Baltic states had no large initial macroeconomic imbalances, unlike Bulgaria, Hungary, Romania, Russia, and Ukraine. ${ }^{15}$ However, they all felt the need to single out an anchor to carry out stabilization. Some countries chose the exchange rate (which was therefore fixed); others chose the money supply (and let the exchange rate float).

\footnotetext{
${ }^{13}$ See, for instance, Borensztein and Masson (1993) for a traditional approach to this issue.

${ }^{14}$ Relative-price adjustment is thought to be politically easier if all prices move upwards, although at a different speeds, rather than if some move upwards and others downwards.

${ }^{15}$ For instance, in Czechoslovakia and the Baltic states the levels of domestic and foreign debt was low, while Bulgaria, Hungary, and Poland had substantial amounts of foreign obligations. In addition, Bulgaria, Romania, and Russia experienced initial liquidity overhang, and Bulgaria, Czechoslovakia, Romania, and Ukraine had extremely low foreign exchange reserves.
} 
First Poland in 1990, followed by Czechoslovakia in 1991, pegged their exchange rates to the U.S. dollar and to a basket of currencies, respectively. At the same time, price liberalization programs were launched, and subsidies were reduced. Priority was given to price stabilization, and the exchange rate was used to curb inflationary pressures. ${ }^{16}$ Price stabilization was only partially successful: in the Czech Republic inflation stabilized at about $8-9 \%$ on annual basis, while in Poland it fell to about $30 \%$. In fact, the Polish authorities had to devalue the zloty in 1991 and change the peg from the U.S. dollar to a basket of currencies; in late 1991 a crawling-peg regime was introduced.

On the other hand, flexible exchange rates applied to other East European countries-Hungary, Bulgaria, Romania, Russia, and Ukraine. Allegedly, this choice was justified by their vulnerable balance of payment position, heavy foreign debt, limited foreign exchanges reserves, monetary overhang, and lack of access to foreign financing. In particular, Hungary adopted an adjustable peg regime, whereas the remaining countries went for a free-floating regime as early at 1991. It has been claimed that this strategy allowed them to open and liberalize their economics, which otherwise would not be possible.

The three Baltic states, Estonia, Lithuania, and Latvia, are a special case. In June 1992, Estonia (and since April 1994 Lithuania) established a fixed exchange rate ${ }^{17}$ regime run by a currency board, whereby the central bank was prohibited from issuing domestic credit (except in the case where base money does not exceed gross foreign reserves) and from serving as a lender of last resort. ${ }^{18}$ Latvia (and Lithuania, until April 1, 1994) adopted a regime of floating exchange rates. The distinctive feature of these countries is their economic success, despite their late start (1992, as opposed, say, to Poland, where transition began two years earlier), and their different approach to the exchangerate policy.

\section{The New Story Once More}

It is clear that all the Eastern European countries (except the Baltic states) have achieved only limited commodity convertibility, that is, current-account convertibility with a variety of trade restrictions. By doing so, various goals were attained. First, compliance with the requirements presented by the international financial institutions could be rightly claimed, and credibility could be acquired with reference to international standards. In addition, partial trade liberalization accompanying convertibility actually led to some real changes in the domestic economy, a more efficient relativeprice structure, thereby showing to public opinion that transition was under way. On the other hand, the limitations to free trade enabled politicians to carry out transition gradually, and therefore smooth social unrest and possible sources of resistance; they also provided ample scope for protection and therefore rents. In short, limited convertibility allowed policy makers to stay in office and maximize their income by creating a bargaining game.

In this light, it is not surprising that the cases corresponding to the lower degrees of convertibility are often situations characterized by high degrees of political instability

\footnotetext{
${ }^{16}$ In both countries the decision to peg the exchange rate was also influenced by a commitment of the international community to provide financial resources to maintain the exchange rate at the chosen level.

${ }^{17}$ Estonia pegged its currency to the Deutsche Mark, Lithuania to the U.S. dollar.

${ }^{18}$ Actually, Hansson and Sachs (1994) have argued that the Estonian case corresponds to a quasi-currency board, since a "pure" currency board backs only cash, whereas the Estonian version backs base money.
} 
and where politicians necessarily have shorter time horizons. On the other hand, convertibility is greater in those countries where pretransition relative prices for tradables were closer to free market prices (the ideal configuration). This is confirmed by the fact that such economies have been much more successful in their efforts to redirect their trade flows from an intra-CMEA pattern to a world wide pattern.

On the contrary, the achievement of full convertibility (both on the current and the capital account) in the Baltic states is strictly connected with the dimensions of those economies. As has been mentioned in the nominal exchange rate discussion in Section II, in small countries social controls are higher and the scope for rent seeking is much lower. Therefore, politicians tend to ignore rent extraction and aim at long-term political appointment. Personal prestige and overall economic performance become highpriority goals, to be pursued irrespective of the initial relative-price structures. ${ }^{19}$

As pointed out in the real exchange rate discussion in Section IV, the common real-exchange-rate strategy has been characterized by fixing such a rate at an initially high (that is, weak) level, and then letting it appreciate as the price of nontradables failed to adjust to the "market" level. This strategy was surely dictated by the need to accommodate macro-imbalances and choices as regards convertibility and the anchor for prices. But it had some rent-seeking implications as well. The initial depreciation created a bargaining game with producers in the nontradable sectors, who looked for some kind of protection. Whereas the subsequent appreciation kept the game going with nontradable producers, politicians could thus threaten drastic and motivated cuts in protection, and start a new game with tradable producers (who would seek protection, in turn).

As for the nominal exchange-rate regime, the traditional view is well known:

\begin{abstract}
Fixed exchange rates are likely to be more desirable, the more open the economy is, in the sense of being subject to external nominal shocks, and the more integrated it is with its neighbours. [Frenkel et al., (1991), p.9].

When domestic shocks are monetary, the conventional view is that maintaining a fixed exchange rate would be more effective in stabilizing output. [...] In contrast, when the domestic shocks are real, the exchange rate should be adjusted to stabilize output by generating (or withdrawing) external demand. [. . .] Generally speaking, to the extent that the policy aims at stabilizing output in the face of transitory shocks, the exchange rate should be adjusted when shocks originate abroad or in the domestic goods market, but should be fixed when shocks originate in the domestic money market. [Aghevli et al., (1991), p. 6].
\end{abstract}

Thus, fixed exchange rates are assumed to be more suitable to relatively open economies (so that external nominal shocks do not imply real consequences and do not lead to uncertainty). The opposite is argued for relatively closed economies, where domestic (real) adjustment is assumed to be made easier by using the nominal exchange rate as well, so as to control aggregate demand. ${ }^{20}$ It would then follow that, since a transition economy by definition undergoes major real shocks, the adoption of a flexible exchange-rate regime should have been a matter of course.

Yet, the transition experience has shown that several among the countries involved tried at least once to adopt a fixed exchange rate (although some of them failed to keep it so even before the regime became operational), whereas others went straight for a

\footnotetext{
${ }^{19}$ Additional examples are provided by the recent economic developments in Slovenia and Croatia

${ }^{20}$ See also Borensztein and Masson (1993) for a more problematic approach.
} 


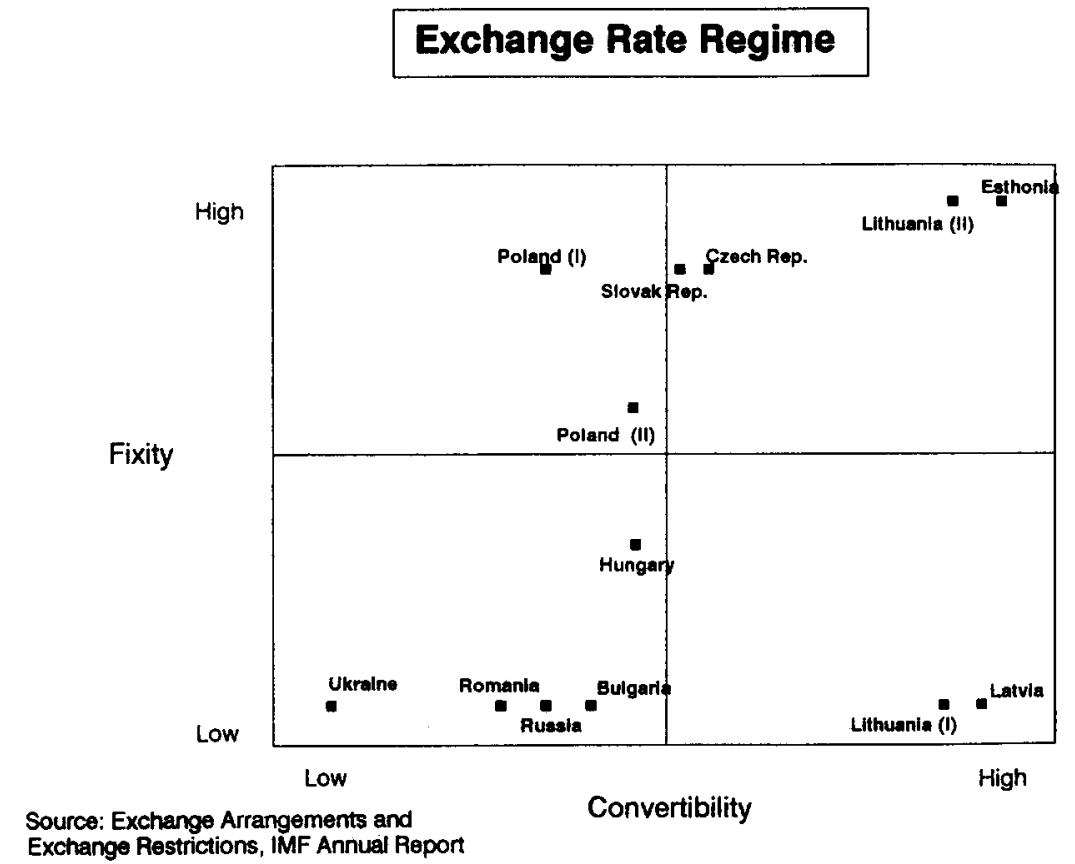

FIG. 1.

flexible regime. Furthermore, contrary to conventional wisdom, fixed exchange rates were sought and finally adopted by those countries with a credible enough government, not by those who needed credibility very badly.

To solve this inconsistency, this paper has taken the view that many policy makers tried to go for some kind of fixed exchange-rate regime to create and extract rents, with the notable exception of the Baltic states. In some countries the overall initial situation was compatible with a gradual-transition outlook, so that a fixed exchange would have been manageable. That is, not only there were no dollarization problems, but macroeconomic disequilibria would not come to the surface too rapidly. In these cases, fixed rates were adopted and rents created. In other countries the initial disequilibria were just too sharp to be compensated by reasonable price intervention; flexible rates were the only choice available, the alternative being dollarization. In these cases, however, rents were created or preserved by limiting the degree of convertibility.

The graph above presents the position of the various countries as regards the existing correlation between the degree of currency convertibility and the level of exchange-rate flexibility at the end of $1994 .^{21}$ By and large, our conclusions seem to be confirmed.

\footnotetext{
${ }^{21}$ The evaluation of the degree of convertibility and of the level of exchange-rate flexibility is based on the information contained in several recent studies in the various issues of the IMF's Annual Report, "Exchange Arrangements and Exchange Restriction," as well as on our own estimates. In particular, the degree of convertibility has been assumed to depend on (i) the regime for opening foreign-currency deposit accounts by both residents and nonresidents, (ii) the degree of trade liberalization, (iii) restrictions on payments for and proceeds from invisibles, including limitations to travel allowances, (iv) the regime for foreign investments by residents, and (v) the existence of bilateral payment arrangements and payment restrictions.
} 
Countries going through smooth transition and where pretransition relative prices in tradables were closer to free-market prices have favored fixed exchange rates with high convertibility (Estonia, Lithuania, the Czech Republic, and the Slovak Republic). The opposite seems to be true for countries undergoing "troubled" transition, where the relative-price structure is greatly distorted (Bulgaria, Russia, and Ukraine) ${ }^{22}$

Within this framework, currency support commitments granted by the international community were surely welcome by the Eastern-European authorities, but not because such support would help keep the exchange rate fixed. Rather, it was welcome for domestic political reasons, in that a public international endorsement of their policies would strengthen their political status.

\section{References}

Aghevl, B., Khan, M., and Montiel, P. (1991). Exchange Rate Policy in Developing Countries: Some Analytical Issues. IMF Occasional Paper. 78(March): .

Balassa B. (1964). The Purchasing Power Doctrine: A Reappraisal. Journal of Political Economy. 72(December):584-596.

BennetT A. (1993). The Operation of the Esthonian Currency Board. IMF Staff Papers. 40(June): .

Bofinger, P., SUIndland E., ANd Thanner B. (1993). Prospects of the Monetary Order in the Republics of the FSU. In The Economics of New Currencies. CEPR Conference Report: London.

Borensztein, E., AND MAsson P. (1993). Exchange Arrangements of Previously Centrally Planned Economies. IMF Occasional Paper. 102(February): .

CALvo, G., AND VÉGH, C. (1994). Inflation Stabilization and Nominal Anchors. In Approaches to Exchange Rate Policies. IMF Institute: Washington, D.C.

BRUno, M. (1993). The Economics of New Currencies. CEPR Conference Report: London.

DE Grauwe, P. (1992). The Ecomomics of Monetary Integration, Oxford University Press: Oxford, United Kingdom.

Frenkel, J., Goldstein, M., and Masson, P. (1992). Characteristics of a Successful Exchange Rate System. IMF Occasional Paper. 82(July): .

Greene J., ANd Isard, P. (1991). Currency Convertibility and the Transformation of Centrally Planned Economics. IMF Occasional Paper. 81 (June): .

Guitiàn, M. (1994). The Choice of an Exchange Rate Regime. In Approaches to Exchange Rate Policies. IMF Institute: Washington, D.C.

HANSsON, A., AND SACHS, J. (1994). Monetary Institutes and Credible Stabilization: A Comparison of Experience in the Baltics. Unpublished Converence report. University of Chicago Law School.

Krueger, A.O. (1993). Political Economy of Policy Reform in Developing Countries, MIT Press: Cambridge, Massachusetts.

IMF (1995). Toward Full Convertibility. IMF Survey. February 6:33-37.

Olson, M. (1982). The Rise and Decline of Nations. Yale University Press: New Haven, Connecticut.

Pagano, U. (1993). Can Economics Explain Nationalism? Quaderni del Dipartimento di Economia Politica. Università di Siena, Siena, Italy.

Samuelson, P. (1964). Theoretical Notes on Trade Problems. Review of Economics and Statistics. 66:145154.

Schmieding, H. (1993) Comment on "Prospects of the Monetary Order in the Republics of the FSU." In The Economics of New Currencies. CEPR Conference Report: London.

Stockman, A. (1980). A Theory of Exchange Rate Determination. Joumal of Political Economy. 88:673-698.

\footnotetext{
${ }^{22}$ Poland (I) and Poland (II) refer to when the Polish authorities decided to peg the zloty to the dollar (1990), and to when they opted for a crawling-peg regime, respectively.

Similarly, Lithuania (I) and Lithuania (II) refer to the flexible-regime period (before April 1994) and to the fixed-regime period (after April 1994), respectively.
} 